Supporting information for

\title{
In Vivo Imaging of Hypoxia Associated with Inflammatory Bowel Disease by a Cytoplasmic Protein-Powered Fluorescence Cascade Amplifier
}

Yibo Zhou, ${ }^{\dagger}$ Sheng Yang, ${ }^{\dagger} * *$ Jingru Guo,${ }^{\dagger}$ Hao Dong, ${ }^{\dagger}$ Keyi Yin,${ }^{\dagger}$ Weitao Huang, ${ }^{\S}$ and

$$
\text { Ronghua Yang }{ }^{\dagger, \star * *}
$$

${ }^{\dagger}$ Hunan Provincial Key Laboratory of Cytochemistry, School of Chemistry and Food Engineering, Changsha University of Science and Technology, Changsha, 410114, P. R. China.

$\$$ State Key Laboratory of Chemo/Biosensing and Chemometrics, College of Chemistry and Chemical Engineering, Hunan University, Changsha, 410082, P. R. China.

$\S$ State Key Laboratory of Developmental Biology of Freshwater Fish, Hunan Provincial Key Laboratory of Microbial Molecular Biology, College of Life Science, Hunan Normal University, Changsha, 410081, P. R. China.

\section{Table of Contents}

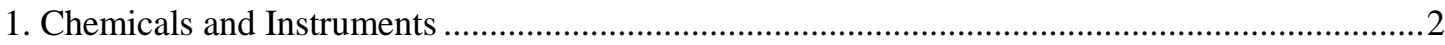

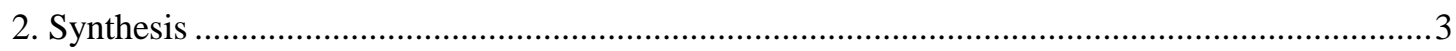

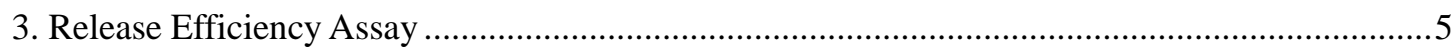

4. MTT Assays ………

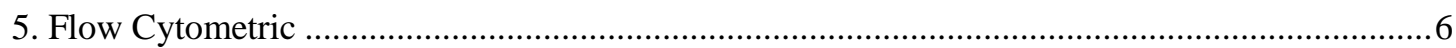

6. Transmission Electron Microscopy Analysis …............................................................

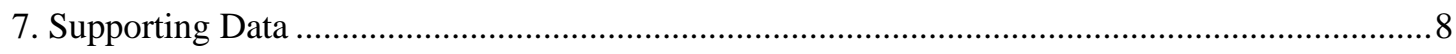

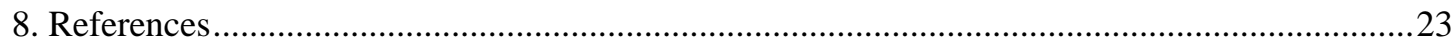




\section{Chemicals and Instruments}

$\beta$-cyclodextrin $(\beta$-CD) and 4-(Phenylazo) benzoic acid were purchased from J\&K Scientific (China). Epichlorohydrin (EPI) was obtained from Energy Chemical (Shanghai, China). N-cetyltrimethylammonium bromide (CTAB, $\geq 99 \%$ ), tetraethyl orthosilicate (TEOS, 28\%), 3-aminepropyltrimethoxysilane (APTES, 99\%) were purchased from Alfa Aesar Chemical Ltd. (China). Rat liver microsomes were purchased from CHI Scientific (Jiangsu, China). $\beta$-Nicotinamide adenine dinucleotide 2'-phosphate reduced tetrasodium salt (NADPH) was purchased from Beyotime Biotechnology (Shanghai, China). Dextran sulphate sodium salt (DSS, molecular weight 4000) was obtained from Nanjing Duly Biotech Co.,Ltd (Jiangsu, China). Methyl thiazolyl tetrazolium (MTT) was purchased from Sigma-Aldrich. Commercial hypoxia-sensitive small-molecule fluorescent probe was purchased from Beijing Bright Biotechnology Co., Ltd. (Beijing, China). The HeLa cancer cell lines were provided by the medical college of hunan normal university (China). Seven-weeks-old BALB/c mice were obtained from Hunan Slaccas Jingda Laboratory Animal Co., Ltd. All solutions were prepared and diluted using ultrapure water (18.2 $\mathrm{M} \Omega \mathrm{cm}$ ) from the Millipore Milli-Q system.

Transmission electron microscope (TEM, JEOL 1200 EXII), fourier transforminfrared (FTIR, TENSOR 27 spectrometer), thermo gravimetric analyzer (TGA, DTG-60) and dynamic light scattering (DLS, Malvern Zetasizer 3000HS) were used to characterize the manufacture process of nanoprobe. ${ }^{13} \mathrm{C}$ NMR and ${ }^{1} \mathrm{H}$ spectra were recorded with Invoa 400 spectrometer. Mass spectra were recorded on 
LCQ/Advantage HPLC-Mass spectrotometer. UV-vis absorption spectra were recorded on a Hitachi U-4100 spectrophotometer (Kyoto, Japan). The fluorescence emission spectra were performed on Photon Technology Intl. MTT assay was measured with Benchmark Plus (Bio-Rad Instruments Inc., Japan). Cell fluorescence images were performed on Olympus FV1000-MPE laser scanning confocal microscope (Japan). Flow cytometric analysis was implemented with BD Facscalibur cytometer. The cellular TEM images were obtained with JEOL 1200 EXII scanning and transmission electron microscope (Japan Electron Optics Laboratory, Peabody, MA) in Xiangya Hospital Central South University. The histological images of colon tissue were recorded with microscopy. The IVIS Imaging System (Xenogen) was used for the vivo and organ imaging.

\section{Synthesis}

$\beta$-cyclodextrin polymer $(\boldsymbol{\beta}$-CDP). The $\beta$-CDP was synthesized according to published literature $^{1}$ (Scheme S1A). The dry $\beta$-CD $(10 \mathrm{~g})$ was stirred in $\mathrm{NaOH}$ solution $(15 \mathrm{~mL}, 2.0 \mathrm{M})$ for $2.0 \mathrm{~h}$ at $35{ }^{\circ} \mathrm{C}$ until the solid $\beta$-CD dissolved. Then methylbenzene $(2 \mathrm{~mL})$ was added to react for another $2.0 \mathrm{~h}$. Epichlorohydrin (EPI, 8 $\mathrm{mL}$ ) was added quickly under vigorous stirring conditions and reacted for $4.0 \mathrm{~h}$ at room temperature. After being cooled to room temperature, $\mathrm{HCl}(6.0 \mathrm{M})$ was added cautiously to adjust $\mathrm{pH}$ to 7.0 . Then the product was obtained by filtration and dried under vacuum to afford white solid. Yield was about $80.0 \% .{ }^{13} \mathrm{C}$ NMR $(100 \mathrm{MHz}$, $\left.\mathrm{CDCl}_{3}\right): \delta=104.279,74.496,75.571,83.604,72.894,65.121,59.902,62.709$.

Squarylium Dyes (SQ). The SQ dye was synthesized according to modified synthesis 
method. $^{2}$

BHQ2. 2,5-dimethoxyaniline (1.0 g, $6.53 \mathrm{mmol})$ and $\mathrm{NaNO}_{2}(0.1 \mathrm{~g}, 1.45 \mathrm{mmol})$ was dissolved in DMF $(10 \mathrm{~mL})$ at $0{ }^{\circ} \mathrm{C}$. Then paranitroaniline $(1.0 \mathrm{~g}, 7.25 \mathrm{mmol})$ was dissolved in $\mathrm{HCl}(6 \mathrm{~mL})$ and added dropwise in DMF solution. $\mathrm{HBF}_{4}(6 \mathrm{~mL})$ was added dropwise to the mixture over $0.5 \mathrm{~h}$, then the mixture was stirred at $0{ }^{\circ} \mathrm{C}$ for $1.0 \mathrm{~h}$. The reaction mixture was filtered and the crude product was dissolved in DCM. The residues were extracted with saturated salt water until solid product dissolved in organic phase completely, then the solvent was removed by reduced pressure distillation to afford $1.29 \mathrm{~g}$ compound 2 as red solid. Yield was about $65.0 \% .{ }^{1} \mathrm{H}$ NMR (400 MHz, $\left.\mathrm{CDCl}_{3}\right): \delta=8.30(\mathrm{~d}, 2 \mathrm{H}, \mathrm{J}=9.1 \mathrm{~Hz}), 7.90(\mathrm{~d}, 2 \mathrm{H}, \mathrm{J}=9.0 \mathrm{~Hz}), 7.40(\mathrm{~s}, 2 \mathrm{H})$, $6.35(\mathrm{~s}, 2 \mathrm{H}), 4.61(\mathrm{~s}, 2 \mathrm{H}), 3.98(\mathrm{~s}, 3 \mathrm{H}), 3.90$ (s, $3 \mathrm{H})$. HRMS (ESI): Calcd for $[\mathrm{M}-\mathrm{H}]^{+}, 303.1049$, Found, 303.1.

Subsequently, $\mathrm{NaNO}_{2}(0.1 \mathrm{~g}, 1.45 \mathrm{mmol})$ was dissolved in $\mathrm{H}_{2} \mathrm{SO}_{4}(5 \mathrm{~mL})$ and cooled to $0{ }^{\circ} \mathrm{C}$ in ice bath to obtain the nitrosyl sulfate. Compound $2(0.7 \mathrm{~g}, 2.31 \mathrm{mmol})$ was dissolved in $\mathrm{H}_{2} \mathrm{SO}_{4}(5 \mathrm{~mL})$ at room temperature and then stirred for $20 \mathrm{~min}$ in ice bath. After complete dissolution, nitrosyl sulfate was added dropwise to compound 2 solution, and the mixture was stirred for $1.0 \mathrm{~h}$. Then ice cold $\mathrm{HBF}_{4}(50 \mathrm{~mL})$ was slowly added and the mixture was extracted with dichloromethane until the aqueous phase was colourless. The organic phase was pooled and evaporated to yield $0.63 \mathrm{~g}$ diazonium tetrafluoroborate salt. The obtained product was dissolved in THF $(20 \mathrm{~mL})$ and a solution of tert-butyl (3-(methyl(phenyl)amino)propyl)carbamate $(0.79 \mathrm{~g}, 3.0 \mathrm{mmol})$ was added dropwise in THF $(20 \mathrm{~mL})$. The reaction mixture was stirred for $1.0 \mathrm{~h}$ and the 
residue was dissolved in DCM $(50 \mathrm{~mL}) . \mathrm{HCl}(1 \mathrm{M}, 100 \mathrm{~mL})$ was used as extraction agent to wash the organic phase, and the solvent was removed by reduced pressure distillation to afford compound 3 as purple solid (0.59 g, yield 44\%). ${ }^{1} \mathrm{H}$ NMR (400 $\left.\mathrm{MHz}, \mathrm{CDCl}_{3}\right): \delta=8.36(\mathrm{~d}, 2 \mathrm{H}, \mathrm{J}=9.1), 8.05(\mathrm{~d}, 2 \mathrm{H}, \mathrm{J}=9.1 \mathrm{~Hz}), 7.95(\mathrm{~d}, 2 \mathrm{H}, \mathrm{J}=9.1$ Hz), 7.60 (d, 2 H, J=13.3 Hz), 6.95 (d, 2 H, J=9.1 Hz), 4.1 (s, 3 H), 4.05 (s, 3 H), 3.78 (t, 2 H), 3.18 (t, 2 H), 2.75 (s, 3 H), 1.83 (q, 2 H), 1.39 (s, 9 H). HRMS (ESI): Calcd for $[\mathrm{M}-\mathrm{H}]^{+}$, 577.6315, Found, 577.3.

Compound $3(0.3 \mathrm{~g}, 0.52 \mathrm{mmol})$ was dissolved in $\mathrm{CF}_{3} \mathrm{COOH}(5 \mathrm{~mL})$ and stirred for $2.0 \mathrm{~h}$ at room temperature, then the mixture was purified by the silica gel chromatography using $\mathrm{CH}_{2} \mathrm{Cl}_{2} / \mathrm{MeOH}(10: 1$, v/v) to afford BHQ2 as green-purple solid (0.13 g, yield 53\%). ${ }^{1} \mathrm{H}$ NMR (400 MHz, $\left.\mathrm{CDCl}_{3}\right): \delta=8.39(\mathrm{~d}, 2 \mathrm{H}, \mathrm{J}=8.0 \mathrm{~Hz}$ ), $8.06(\mathrm{~d}, 2 \mathrm{H}, \mathrm{J}=8.0 \mathrm{~Hz}), 7.95$ (d, 2 H, J=8.0 Hz), 7.54 (s, 2 H, J=8.0 Hz), 7.49 (s, $2 \mathrm{H})$, $4.07(\mathrm{~d}, 6 \mathrm{H}, \mathrm{J}=20.0 \mathrm{~Hz}), 3.57(\mathrm{~s}, 2 \mathrm{H}), 3.12(\mathrm{~s}, 3 \mathrm{H}), 2.84(\mathrm{~s}, 2 \mathrm{H}), 2.24(\mathrm{t}, 2 \mathrm{H}, \mathrm{J}=6.0$ Hz), 2.06-2.03 (m, 2H). HRMS (ESI): Calcd for [M-H] $]^{+}$, 477.2125, Found, 477.9.

\section{Release Efficiency Assay}

To investigate the hypoxia-activatable dye release, HCFA $(0.1 \mathrm{mg} / \mathrm{mL})$ was placed into beakers containing $2 \mathrm{~mL}$ phosphate buffer with rat liver microsomes (50 $\mu \mathrm{g} / \mathrm{mL})$ and NADPH $(50 \mu \mathrm{M})$. Then the experimental group was bubbled with nitrogen to create hypoxia condition, and the untreated HCFA as a comparison group. At various times, $300 \mu \mathrm{L}$ of solution was removed from the beaker and centrifuged at $8000 \mathrm{rpm}$ for $5 \mathrm{~min}$ at $4{ }^{\circ} \mathrm{C}$, followed by measurement of the supernatant by HPLC. The mobile phase consists of acetonitrile/water $(70: 30 \mathrm{v} / \mathrm{v})$. The quantitative analysis 
was carried out on Inertsil ODS-SP. The column temperature is maintained at $30{ }^{\circ} \mathrm{C}$. The flow rate is set at $1.0 \mathrm{~mL} / \mathrm{min}$, the detection wavelength was $229 \mathrm{~nm}$, and the sample injection volume was $50 \mu \mathrm{L}$. Then HCFA was refreshed and added back. The cumulative release was measured as the released quantity of SQ divided by the total quantity of loaded nanoparticles.

\section{MTT Assays}

HeLa cells $\left(1 \times 10^{4}\right.$ cells per well $)$ were cultured in 96 -well microplates at $37^{\circ} \mathrm{C}$ for $24 \mathrm{~h}$. Then the culture medium was removed and different concentration of HCFA $(0,10,25,50,100$ and $200 \mu \mathrm{g} / \mathrm{mL})$ was added in 96-well. The cells without being treated were used as control group. After incubation for $24 \mathrm{~h}$, cell culture medium was removed and MTT $(100 \mu \mathrm{L})$ was added into each well. After incubation for $4.0 \mathrm{~h}$ in cell incubator, DMSO $\left(150 \mu \mathrm{L}\right.$ well $\left.{ }^{-1}\right)$ was added to well and the plate was shaken for $10 \mathrm{~min}$. Then the cell viability was calculated according to following equation, where $\mathrm{OD}_{570}$ represents the UV-vis absorption density at $570 \mathrm{~nm}$. The whole test was disposed with Tecan microplate (ELISA) reader. ${ }^{3}$

$$
\text { Cell viability }=\left[\mathrm{OD}_{570(\text { (sample) }}-\mathrm{OD}_{570(\text { blank })}\right] /\left[\mathrm{OD}_{570(\text { control })}-\mathrm{OD}_{570(\text { blank })}\right]
$$

\section{Flow Cytometric}

The quantitative fluorescence intensity of cells treated with HCFA $(0.1 \mathrm{mg} / \mathrm{mL})$ was performed with BD FACSCalibur cytometer. HeLa cells were cultured with RPMI 1640 for $24 \mathrm{~h}$ at $37{ }^{\circ} \mathrm{C}$, and the HCFA $(0.1 \mathrm{mg} / \mathrm{mL})$ was added and co-incubated for another $2 \mathrm{~h}$ at different levels of hypoxic conditions $(21 \%, 10 \%, 5 \%$ 
and $0 \%$ ). After that, the cell culture medium was removed and digested with trypsin $(0.5 \mathrm{~mL})$ for $2 \mathrm{~min}$ at $37^{\circ} \mathrm{C}$, then all the cells were collected by centrifugating at 1000 rpm for 4 min. The prepared cells samples were washed with PBS and examined with flow cytometry by counting 20000 events.

\section{Transmission Electron Microscopy Analysis}

HeLa cells were incubated with HCFA $(0.1 \mathrm{mg} / \mathrm{mL})$ in culture medium for $2.0 \mathrm{~h}$, then the cells were digested with trypsin $(0.5 \mathrm{~mL})$ and collected in centrifuge tubes. After that, the cell pellets were fixed with $2.5 \%$ glutaraldehyde in $0.1 \mathrm{M}$ PBS for $2.5 \mathrm{~h}$. Alcohol series $(20 \%, 40 \%, 60 \%, 80 \%$, and $100 \%$ twice) were used to dehydrate the cells sample for $20 \mathrm{~min}$, followed by implanting with Araldite resin at $65{ }^{\circ} \mathrm{C}$ overnight. The slices of sample $(70 \mathrm{~nm})$ were stained with saturated uranyl acetate and $0.2 \%$ Reynolds lead citrate before TEM imaging. The TEM images were collected with JEOL 1200 EXII scanning and transmission electron microscope by placing on TEM grid. 
7. Supporting Data

A

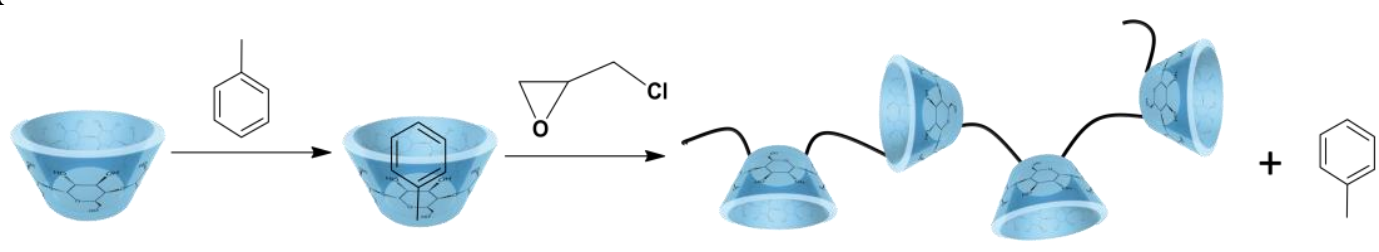

B
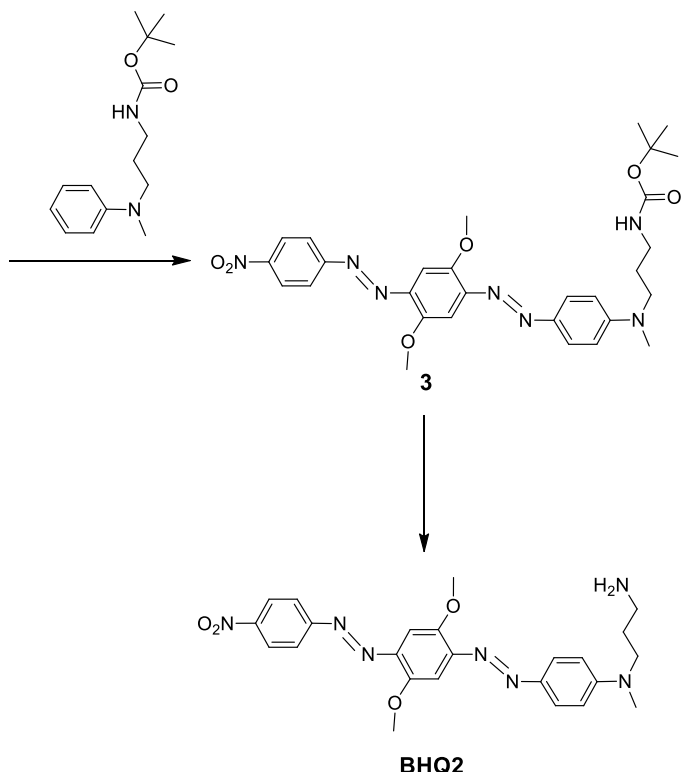

Scheme S1. Synthetic routes of (A) $\beta$-CDP and (B) BHQ2. 

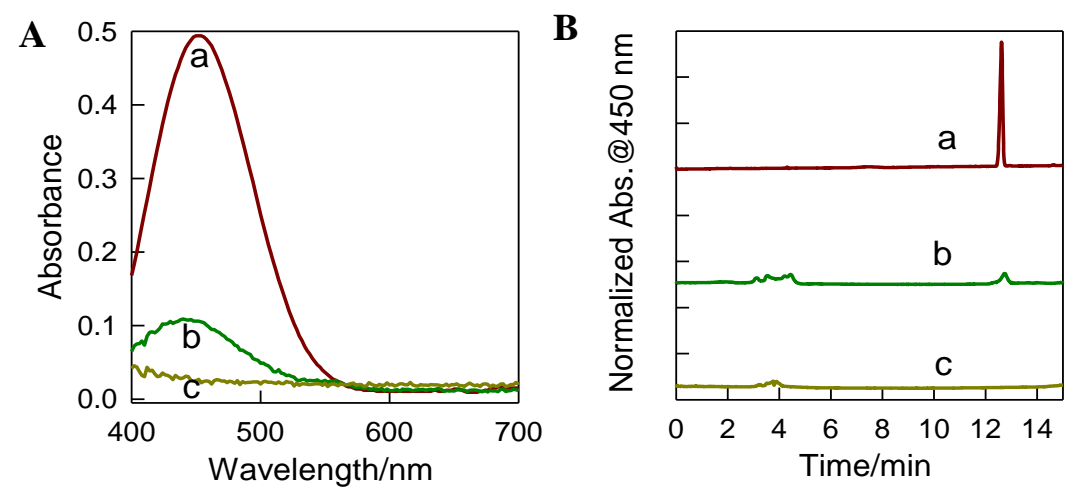

Figure S1. (A) UV-vis absorption spectra of azobenzoic acid under different conditions: (a) azobenzoic acid $(4.0 \mu \mathrm{M}, 1 \%$ acetone, $\mathrm{pH}=7.4)$, (b) azobenzoic acid + liver microsomes + hypoxia, (c) aniline + 4-aminobenzoic acid $(4.0 \mu \mathrm{M}, 1 \%$ acetone, $\mathrm{pH}=7.4$ ). (B) HPLC analysis of (a) azobenzoic acid, (b) reaction product of azobenzoic acid under hypoxic condition, and (c) the mixture of aniline/4-aminobenzoic acid. 


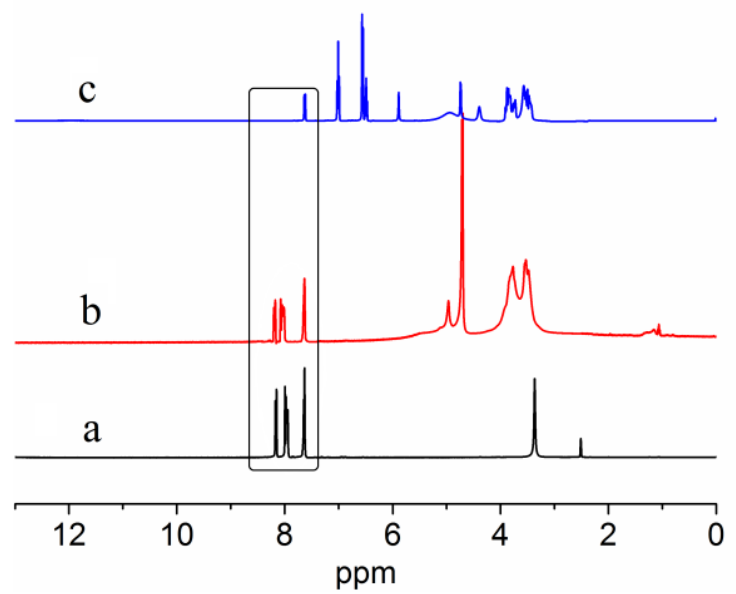

Figure S2. ${ }^{1} \mathrm{H}$ NMR spectra of azobenzoic acid in different condition: (a) azobenzoic acid, (b) $\mathrm{a}+\beta$-CD, (c) $\mathrm{b}+$ liver microsomes +hypoxia. Mark part: the changes of azobenzoic acid shown in Figure 1A. 


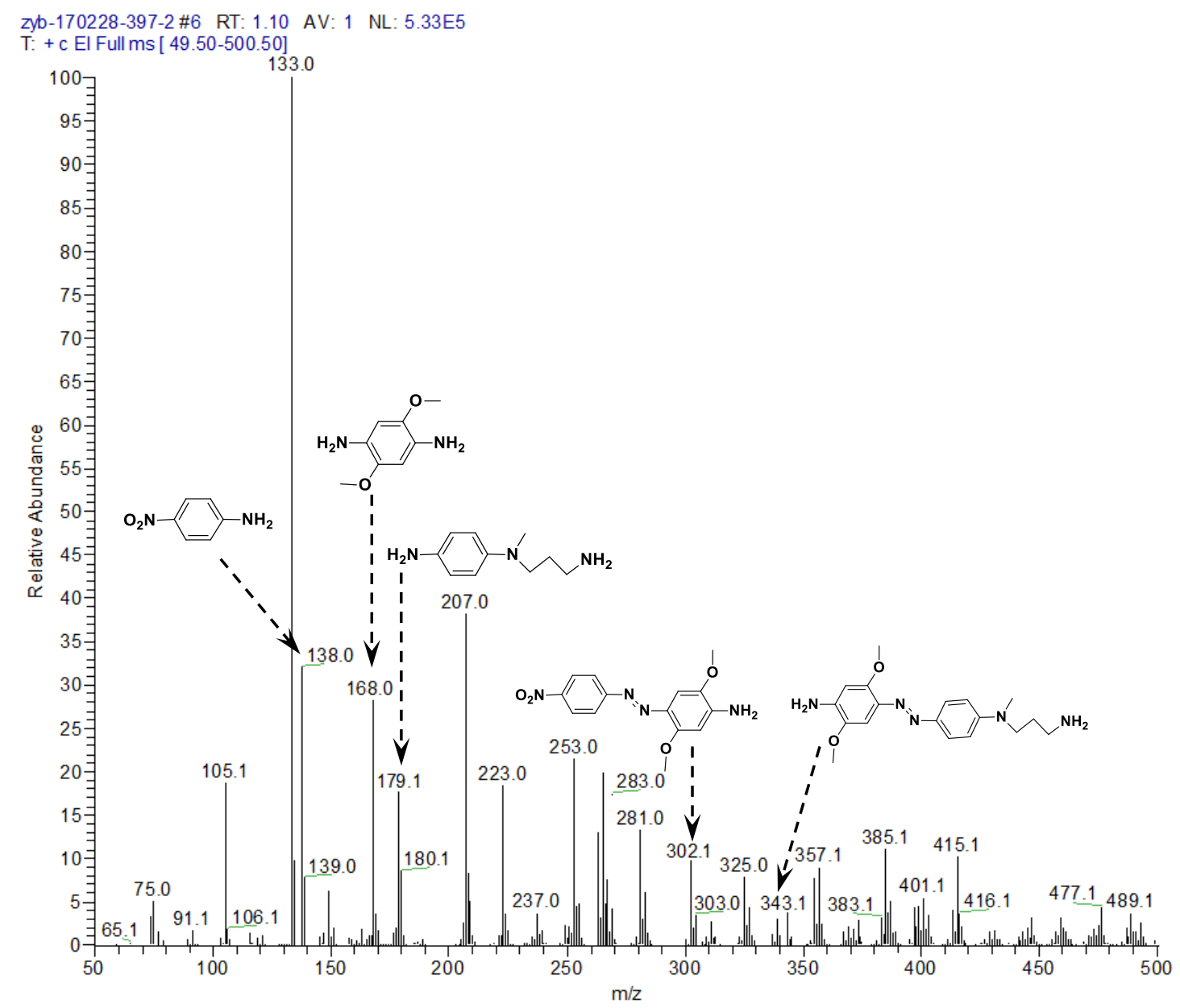

Figure S3. EI-MS of reaction product of BHQ2 under hypoxic condition.

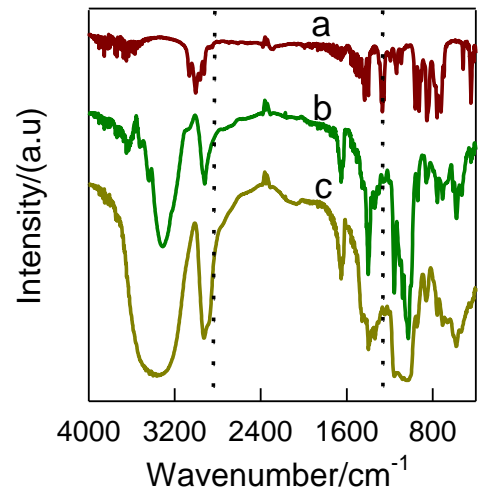

Figure S4. FTIR spectra of (a) epichlorohydrin, (b) $\beta$-CD and (c) $\beta$-CDP. 
Table S1. C NMR spectra of $\beta$-CD and $\beta$-CDP

\begin{tabular}{ccccccccc}
\hline & $\mathrm{C}_{1}$ & $\mathrm{C}_{2}$ & $\mathrm{C}_{3}$ & $\mathrm{C}_{4}$ & $\mathrm{C}_{5}$ & $\mathrm{C}_{6}$ & $\mathrm{C}_{7}$ & $\mathrm{C}_{8}$ \\
\hline$\beta$-CD & 105.020 & 75.221 & 76.259 & 84.269 & 74.985 & 63.404 & & \\
\hline$\beta$-CDP & 104.279 & 74.496 & 75.571 & 83.604 & 72.894 & 65.121 & 59.902 & 62.709 \\
\hline
\end{tabular}
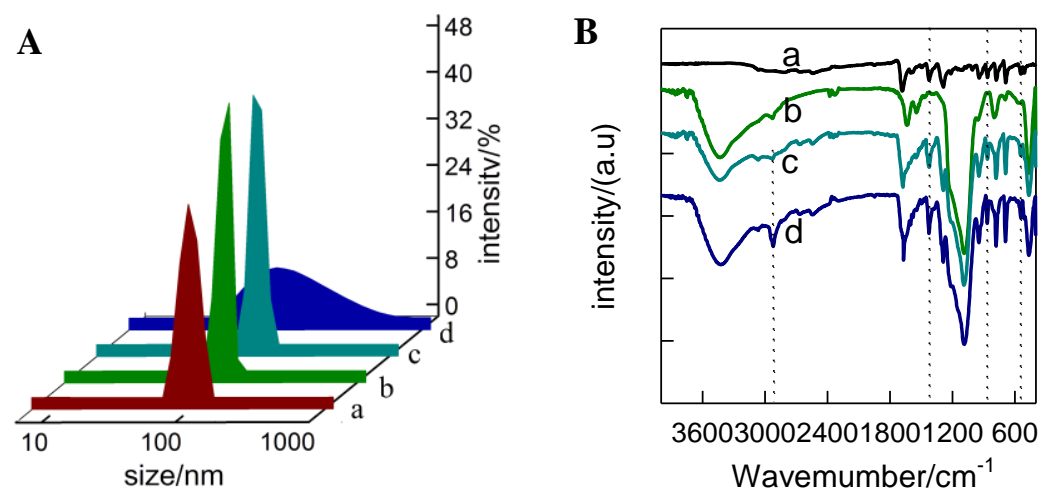

Figure S5. (A) DLS characterization of different functionalized nanoparticles: (a) MSN, (b) MSN-NH2, MSN-azo and (d) HCFA. (B) FTIR spectra of (a) azobenzoic acid, (b) MSN-NH2, (c) MSN-azo and (d) HCFA. 

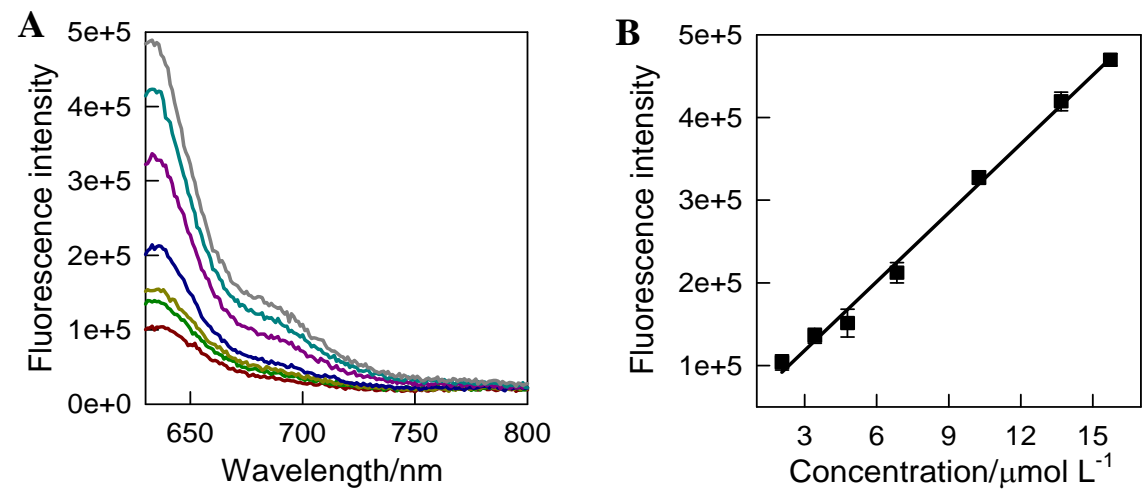

Figure S6. (A) Fluorescence emission spectra of different concentration of SQ in 20 $\mathrm{mM}$ phosphate buffer $(2.051,3.418,4.786,6.837,10.255,13.673$ and $15.724 \mu \mathrm{moL})$. $\lambda_{\mathrm{ex}}=620 \mathrm{~nm}$. (B) The linear relationship between fluorescence intensity and concentration of SQ.
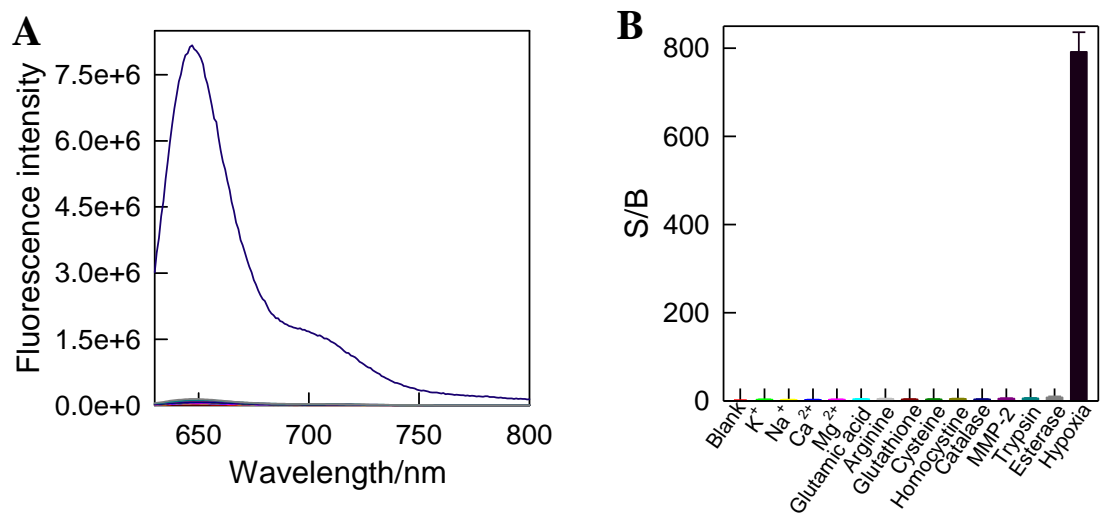

Figure S7. (A) Fluorescence emission spectra and (B) signal-to-background ratios (S/B) of HCFA $(0.1 \mathrm{mg} / \mathrm{mL})$ response to hypoxia $\left(0 \% \mathrm{O}_{2}\right)$ and other biorelevant species in cell lysates from HeLa cells $\left(8 \%\right.$, w/v). $\left(\left[\mathrm{K}^{+}, \mathrm{Na}^{+}, \mathrm{Ca}^{2+}, \mathrm{Mg}^{2+}\right]=5 \mathrm{mM}\right.$, [glutamic acid, arginine, cysteine, homocysteine] $=10 \mu \mathrm{M}$, [glutathione $]=10 \mathrm{mM}$, [catalase, MMP-2, trypsin, esterase] $=10 \mu \mathrm{g} / \mathrm{mL}) . \lambda_{\mathrm{ex}}=620 \mathrm{~nm}$. 

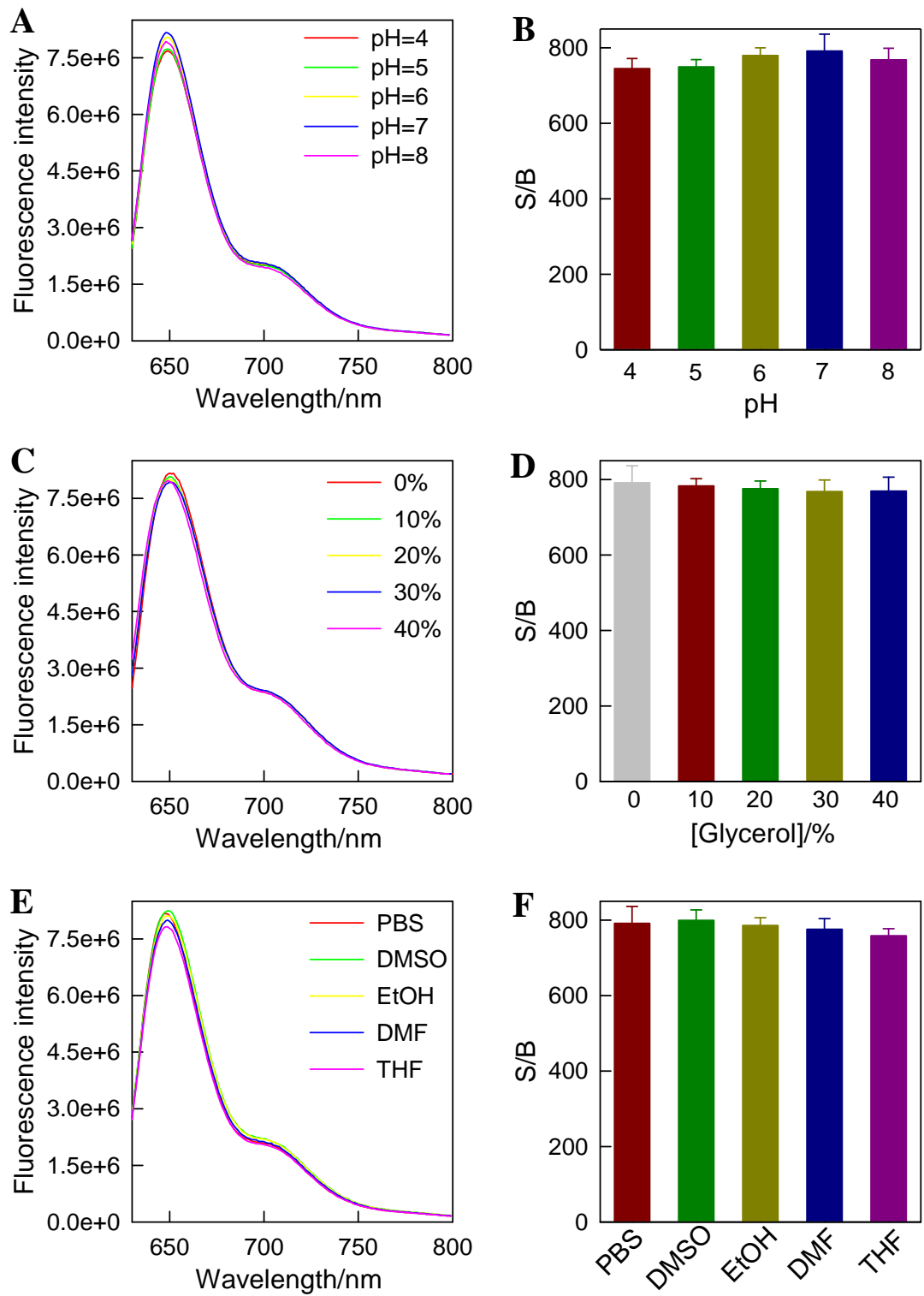

Figure S8. Fluorescence emission spectra and signal-to-background ratios (S/B) of HCFA $(0.1 \mathrm{mg} / \mathrm{mL})$ response to hypoxia $\left(0 \% \mathrm{O}_{2}\right)$ in solution under different conditions: (A, B) $\mathrm{pH},(\mathrm{C}, \mathrm{D})$ solution viscosity (water/glycerol system) and $(\mathrm{E}, \mathrm{F})$ solvents $(5 \% \mathrm{v} / \mathrm{v}) \cdot \lambda_{\mathrm{ex}}=620 \mathrm{~nm}$. 


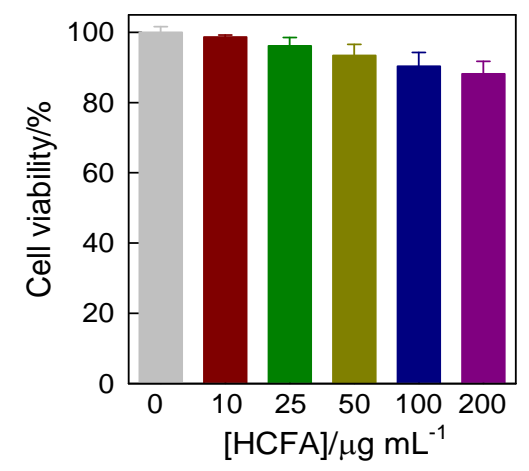

Figure S9. Cell viability study of HeLa cells incubated with different concentrations of HCFA.

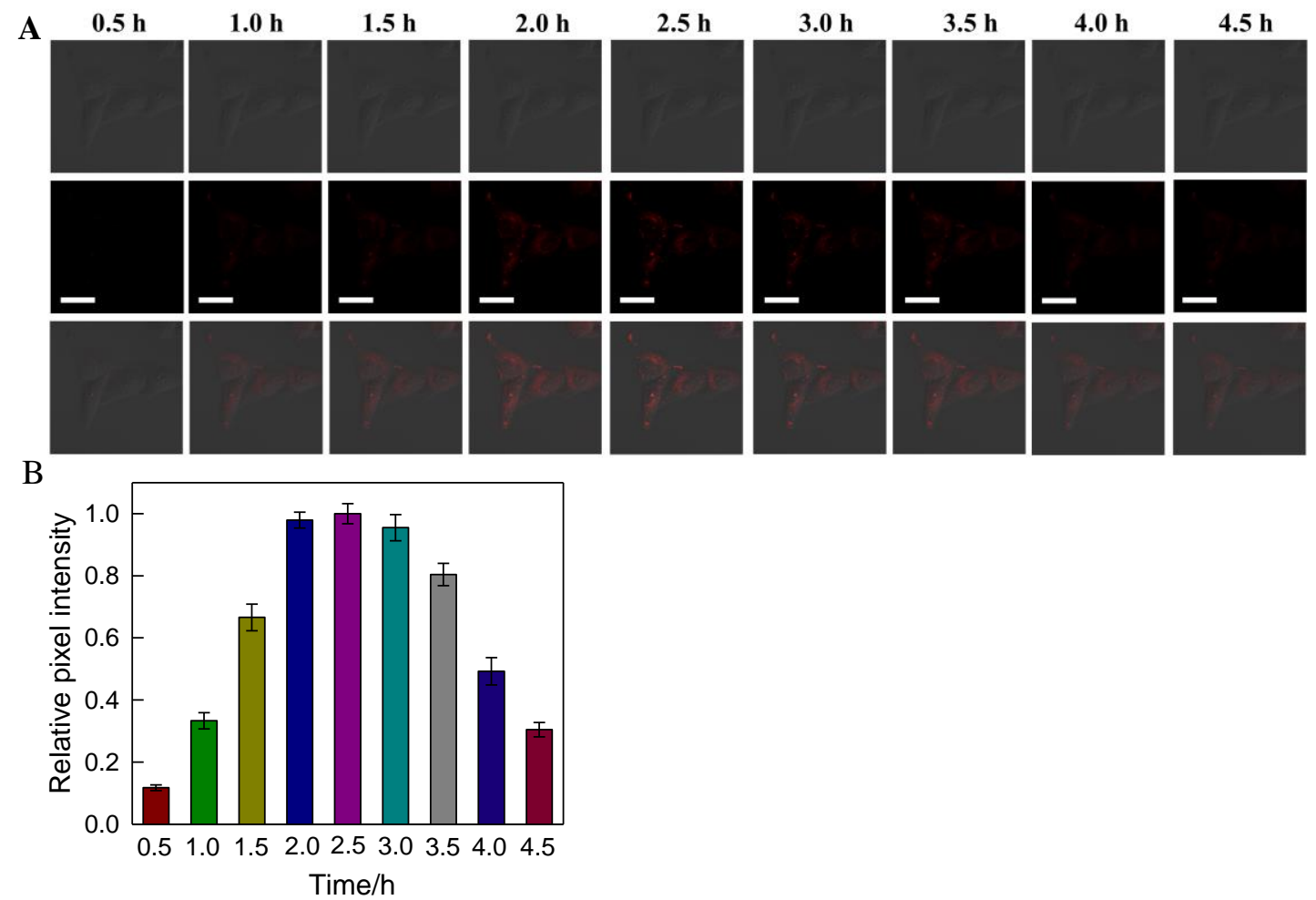

Figure S10. (A) Time course of confocal images of HeLa cells incubated with HCFA $(0.1 \mathrm{mg} / \mathrm{mL}) . \lambda_{\mathrm{ex}}=633 \mathrm{~nm} ; \lambda_{\mathrm{em}}=645-700 \mathrm{~nm}$. (B) Normalized fluorescence intensity of HeLa cells incubated with HCFA $(0.1 \mathrm{mg} / \mathrm{mL})$ for different time, the pixel intensity from image at $2.5 \mathrm{~h}$ is defined as 1.0 . The results are presented as mean: standard deviation ( $\mathrm{n}=3$ ). Scale bar: $20 \mu \mathrm{m}$. 


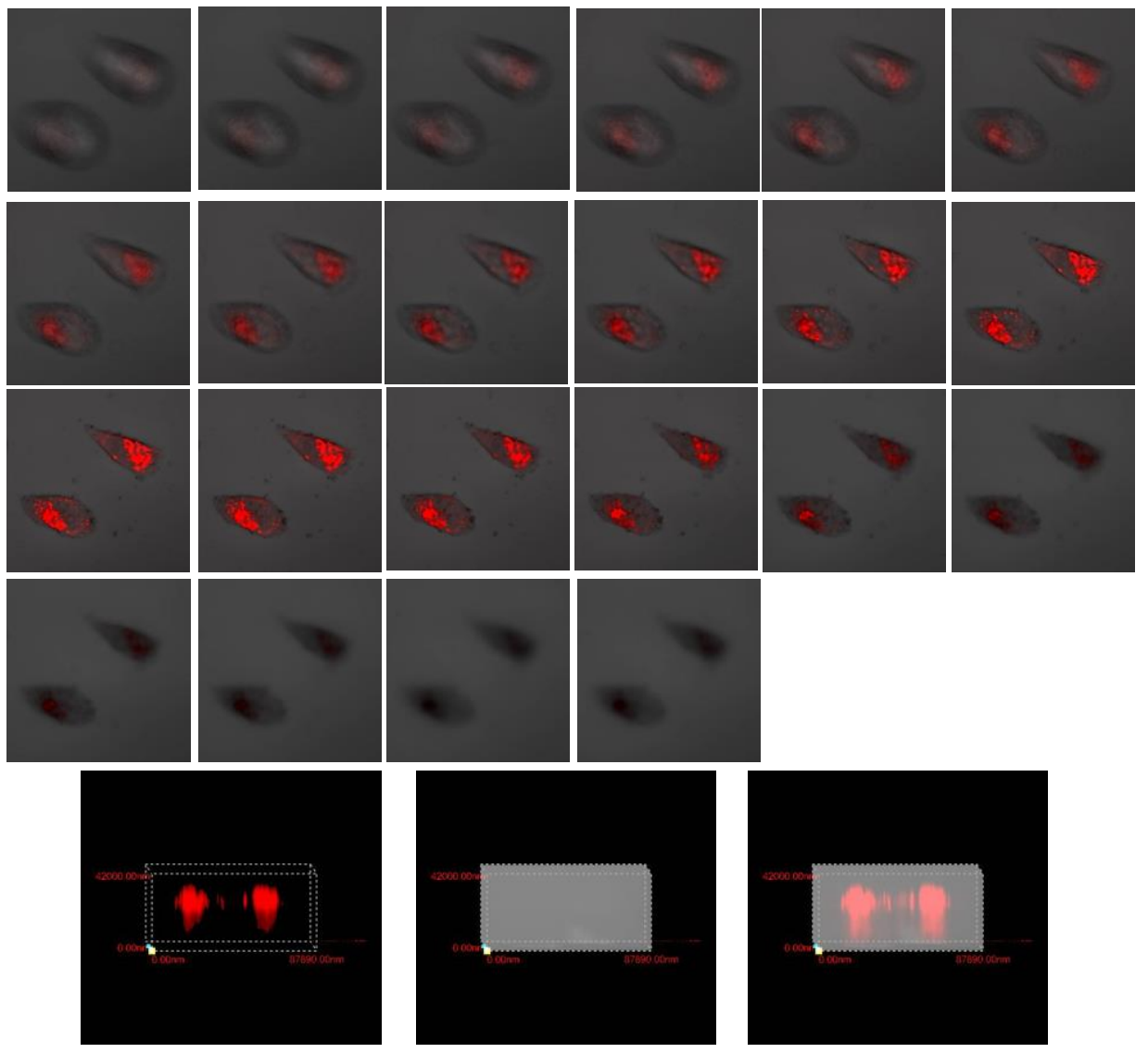

Figure S11. Z-stack gallery images of intracellular HCFA $(0.1 \mathrm{mg} / \mathrm{mL})$. 

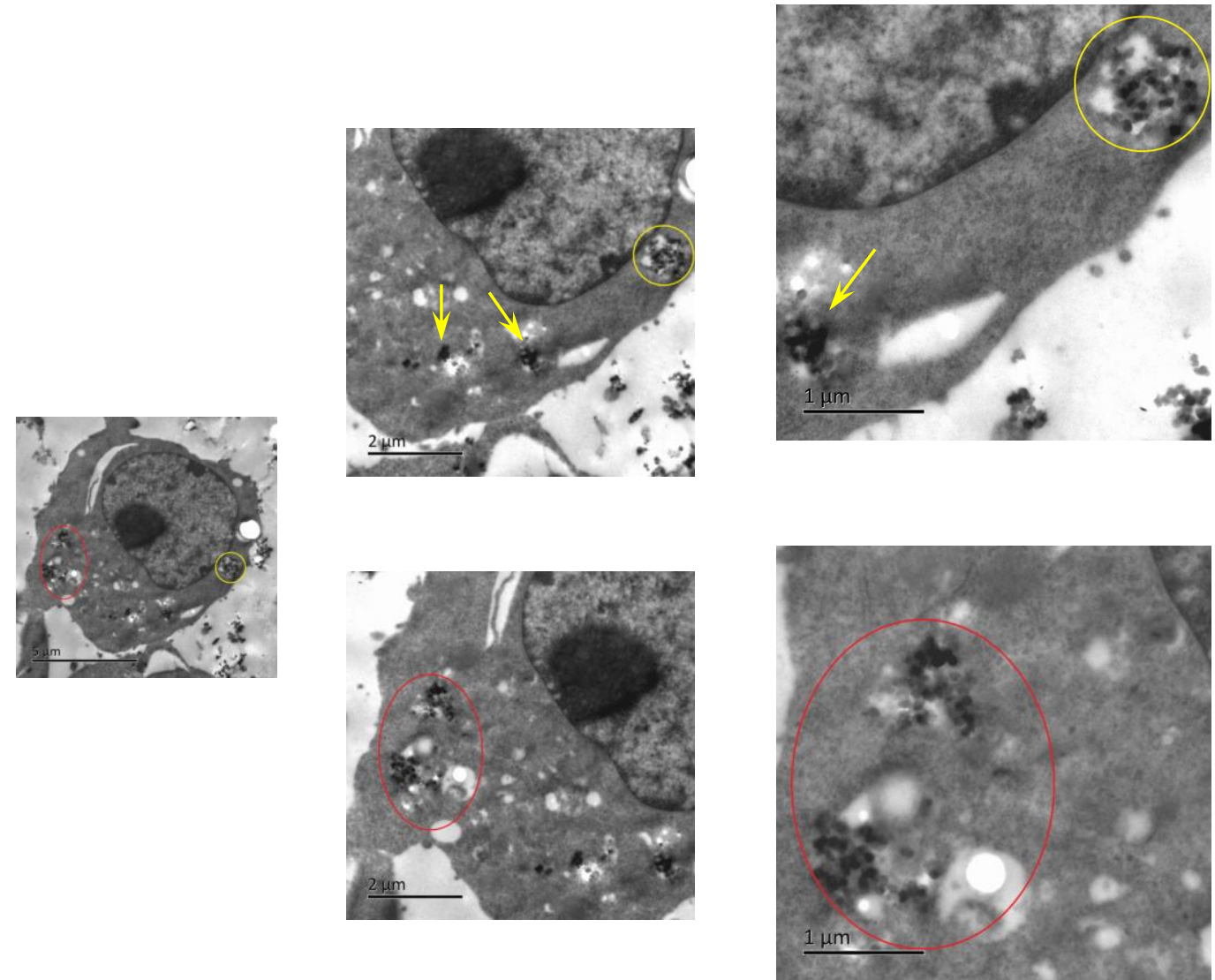

Figure S12. Bio-TEM images of subcellular localization of HCFA in HeLa cells.

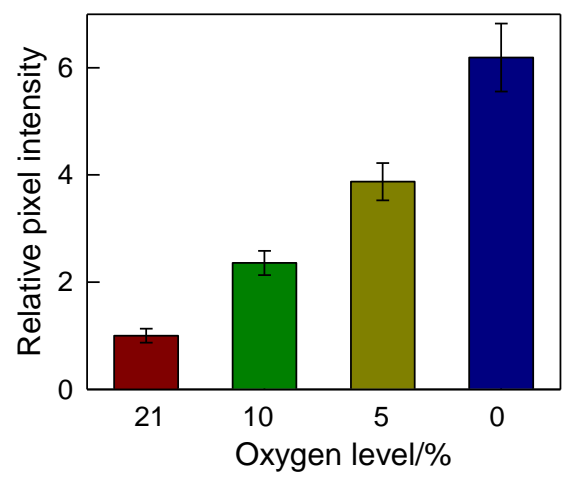

Figure S13. Normalized fluorescence intensity of different hypoxic conditions in HeLa cells with $\mathrm{HCFA}\left(0.1 \mathrm{mg} / \mathrm{mL}, 21 \%, 10 \%, 5 \%, 0 \% \mathrm{O}_{2}\right)$, the pixel intensity from HCFA at $21 \%$ oxygen is defined as 1.0 . The results are presented as mean: standard deviation $(n=3)$. 


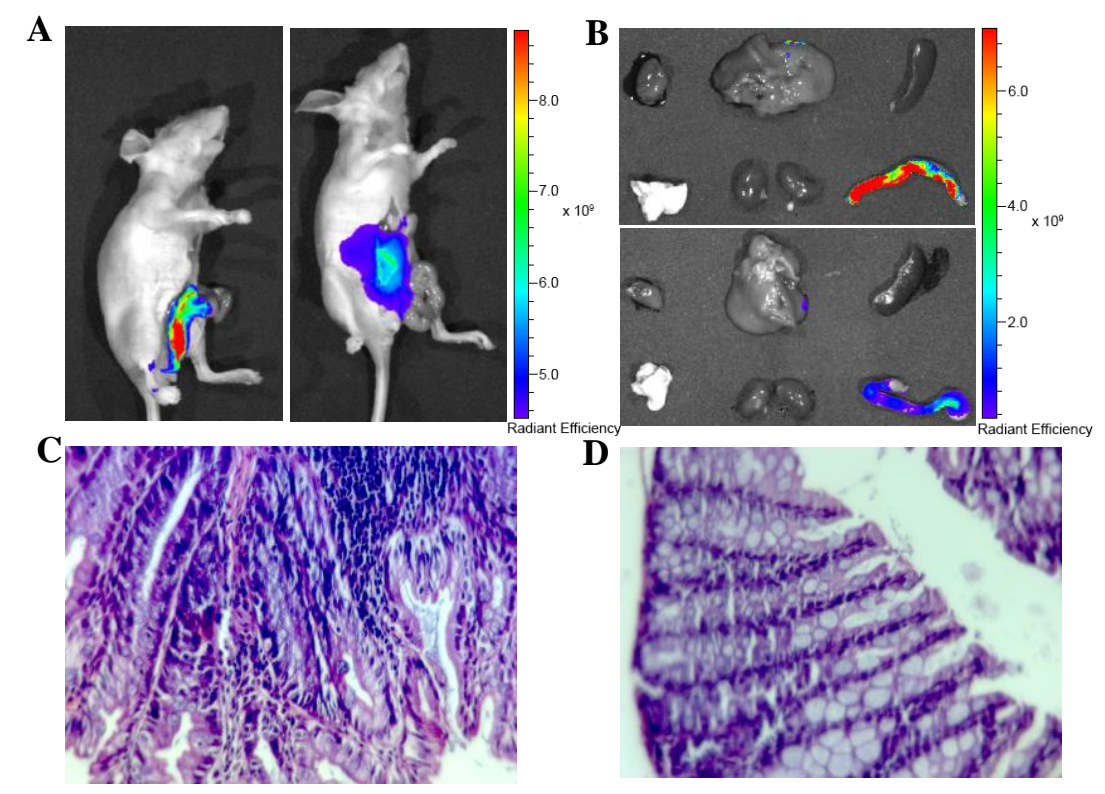

Figure S14. (A) Whole-body fluorescent images (pseudo-color) of acute colitis group (left) and control group (right) after intraperitoneal injection of HCFA (1.0 mg/mL). (B) Fluorescent images of organs dissected from acute colitis group (above) and control group (below). Haematoxylin and eosin-stained slices $(\times 20)$ of $(C)$ inflamed colon and (D) normal colon. (pink staining from the eosin dye and blue staining from the hematoxylin dye). $\lambda_{\mathrm{ex}}=630 \mathrm{~nm} ; \lambda_{\mathrm{em}}=690-740 \mathrm{~nm}$. 


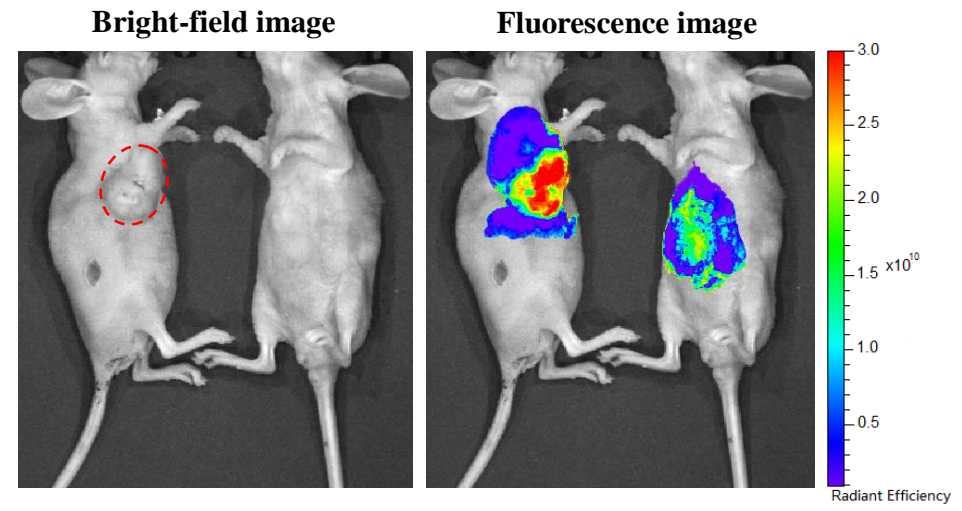

Figure S15. Whole-body bright-field and fluorescent images (pseudo-color) of HeLa subcutaneous xenograft nude mice (left) and acute colitis nude mice after intraperitoneal injection of HCFA $(1.0 \mathrm{mg} / \mathrm{mL})$. The region marked in bright-field image is tumor. $\lambda_{\mathrm{ex}}=630 \mathrm{~nm} ; \lambda_{\mathrm{em}}=690-740 \mathrm{~nm}$. 


\section{${ }^{1} \mathrm{H}$ NMR, ${ }^{13} \mathrm{C}$ NMR and HRMS (ESI)}

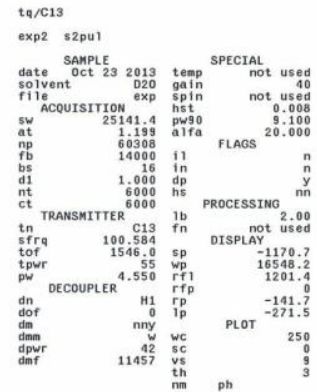

$$
\beta-C D
$$
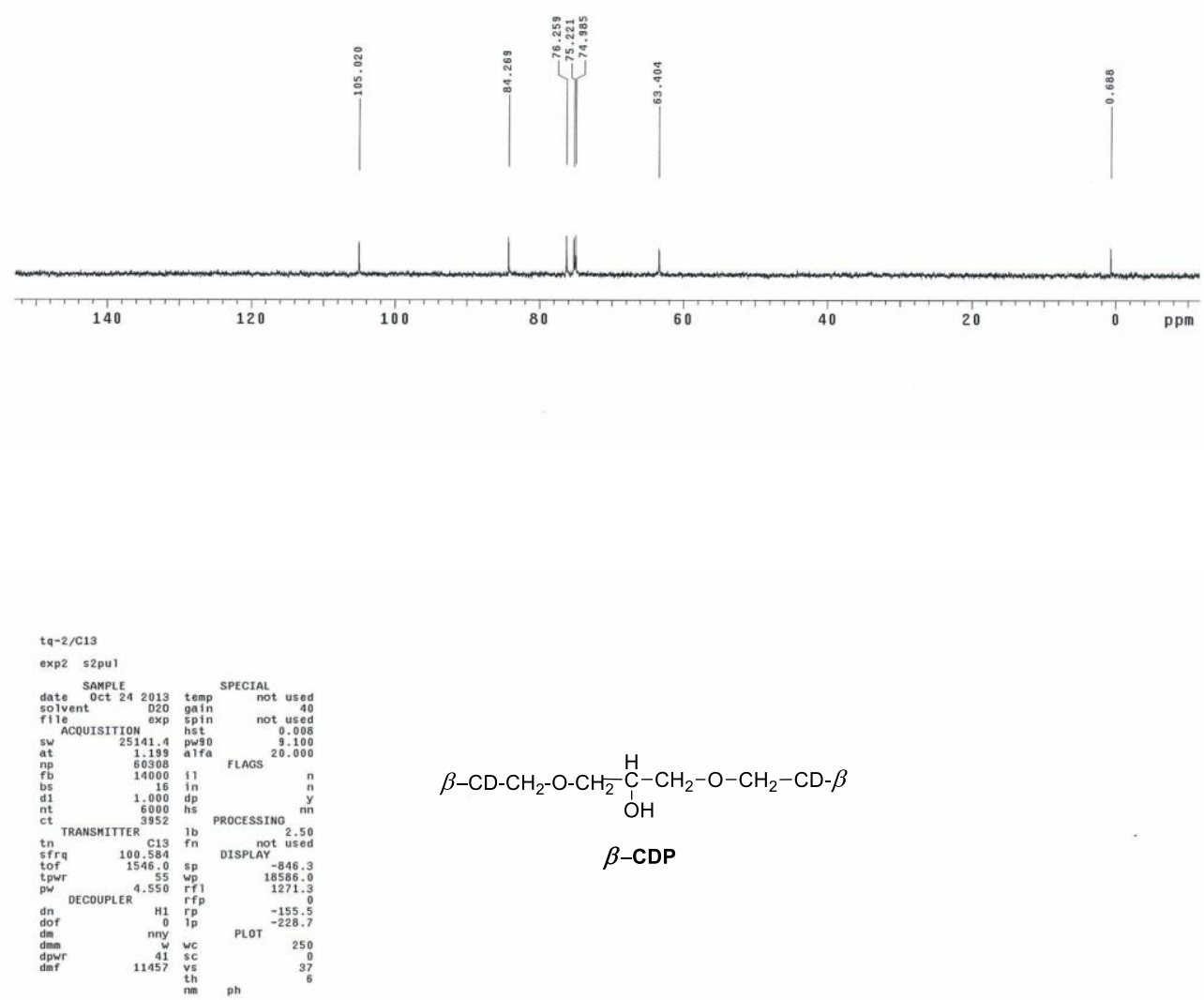

$$
\begin{gathered}
\beta-\mathrm{CD}-\mathrm{CH}_{2}-\mathrm{O}-\mathrm{CH}_{2}-\underset{\mathrm{O}}{\mathrm{O}}-\stackrel{\mathrm{H}}{\mathrm{C}} \mathrm{CH}_{2}-\mathrm{O}-\mathrm{CH}_{2}-\mathrm{CD}-\beta \\
\beta-\mathrm{CDP}
\end{gathered}
$$

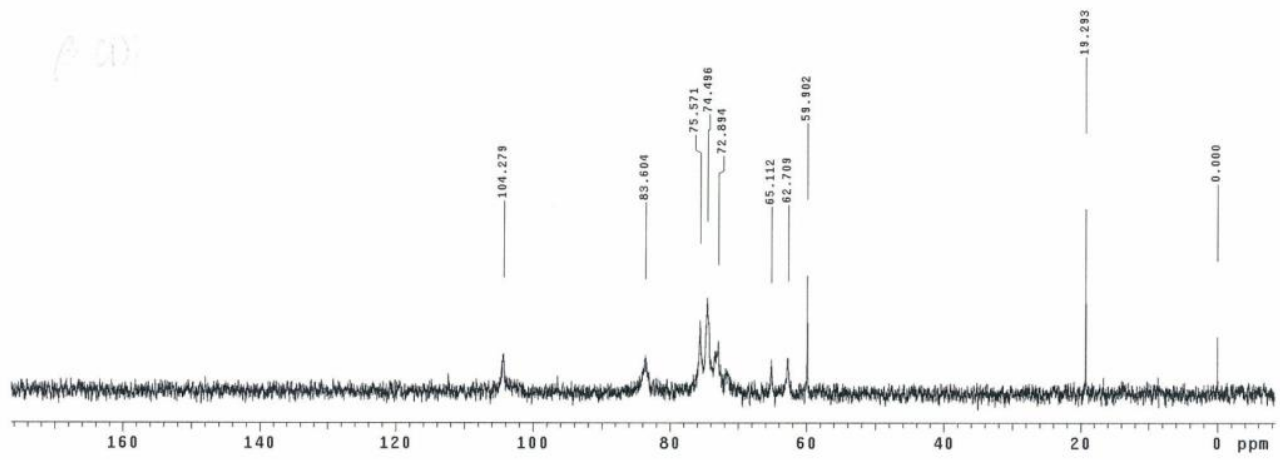




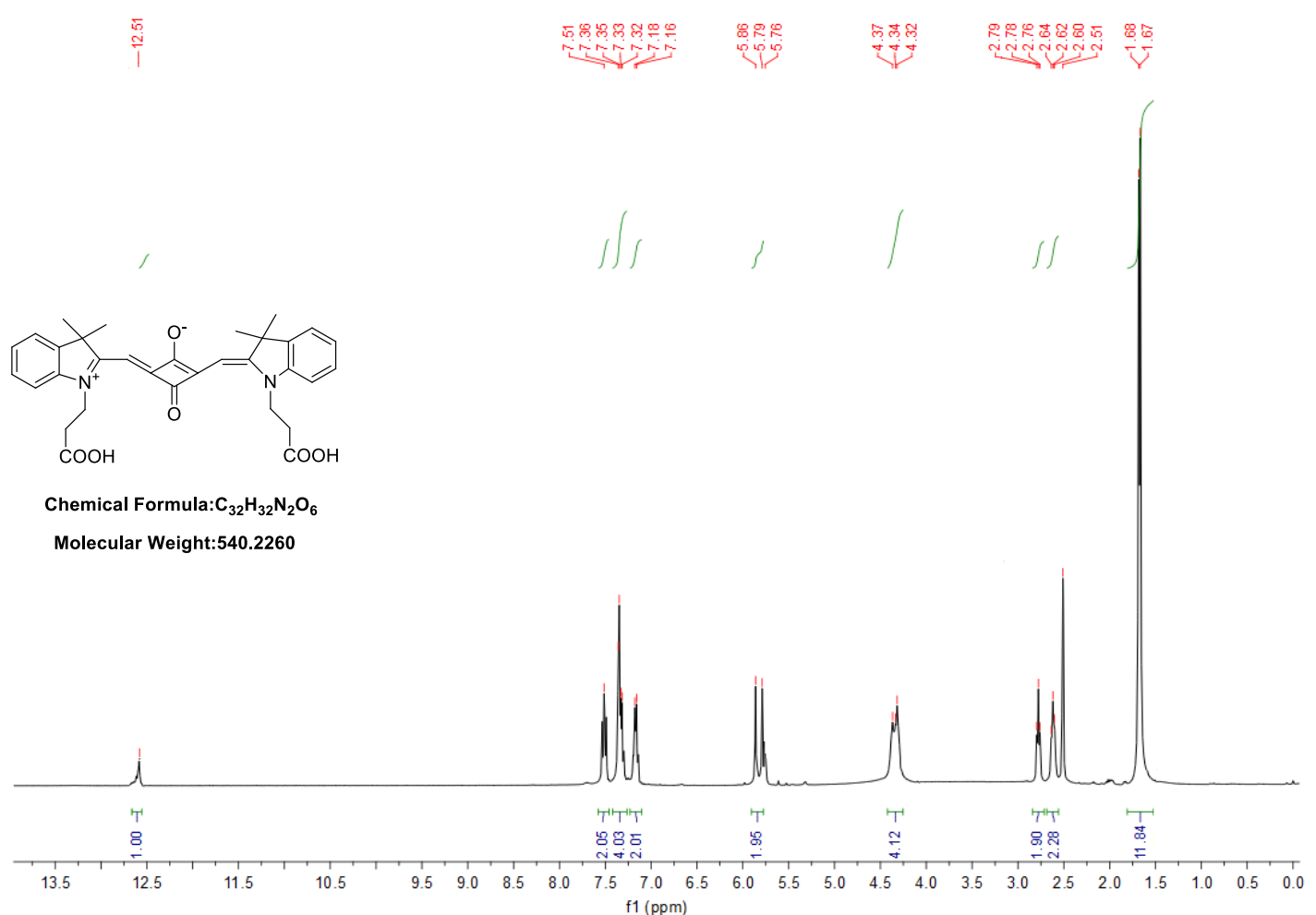

zxf-160310-538 \#16 RT: $0.31 \quad$ AV: $1 \quad$ NL: 2.89E5

T: - c ESI ms [ 50.00-1000.00]

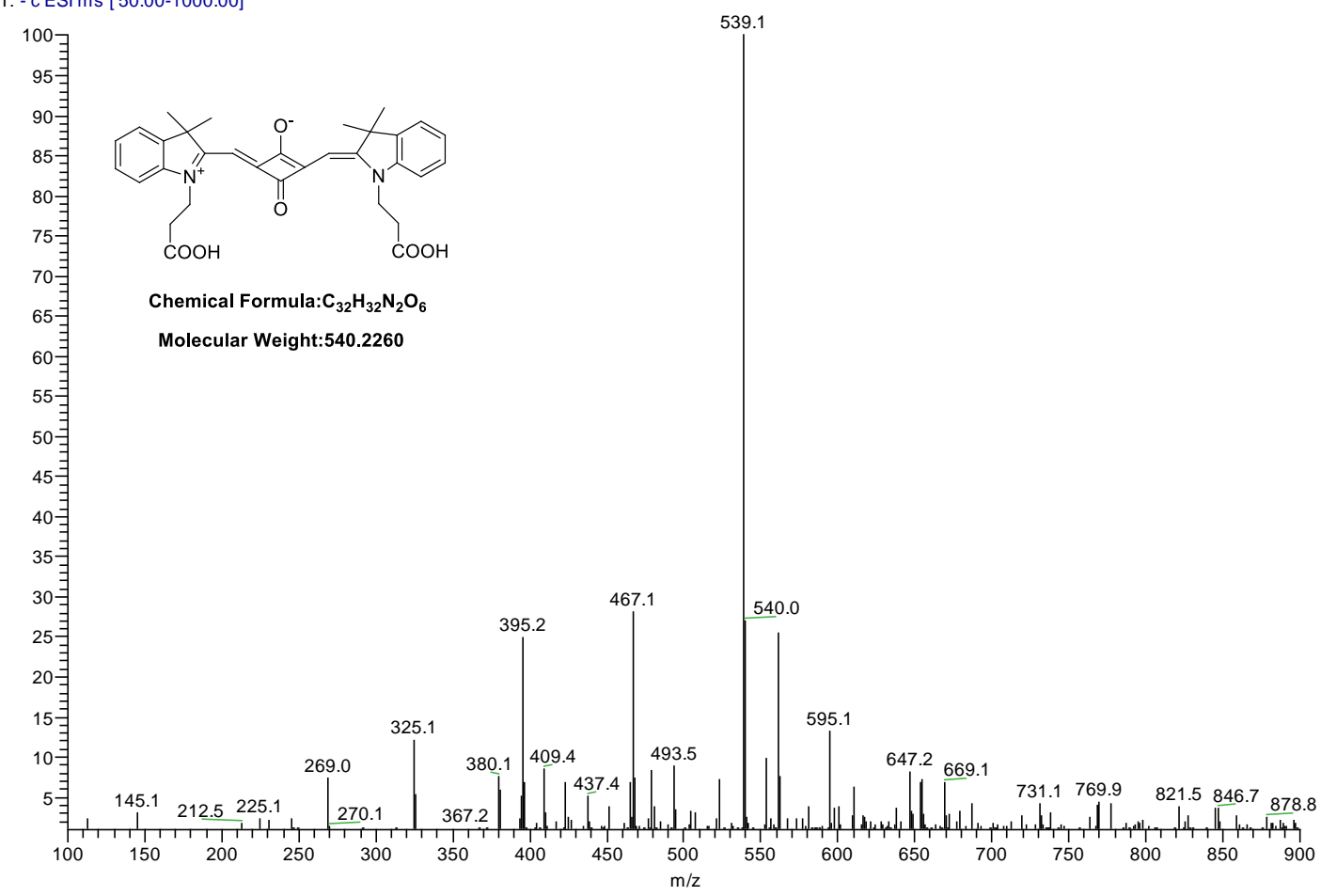




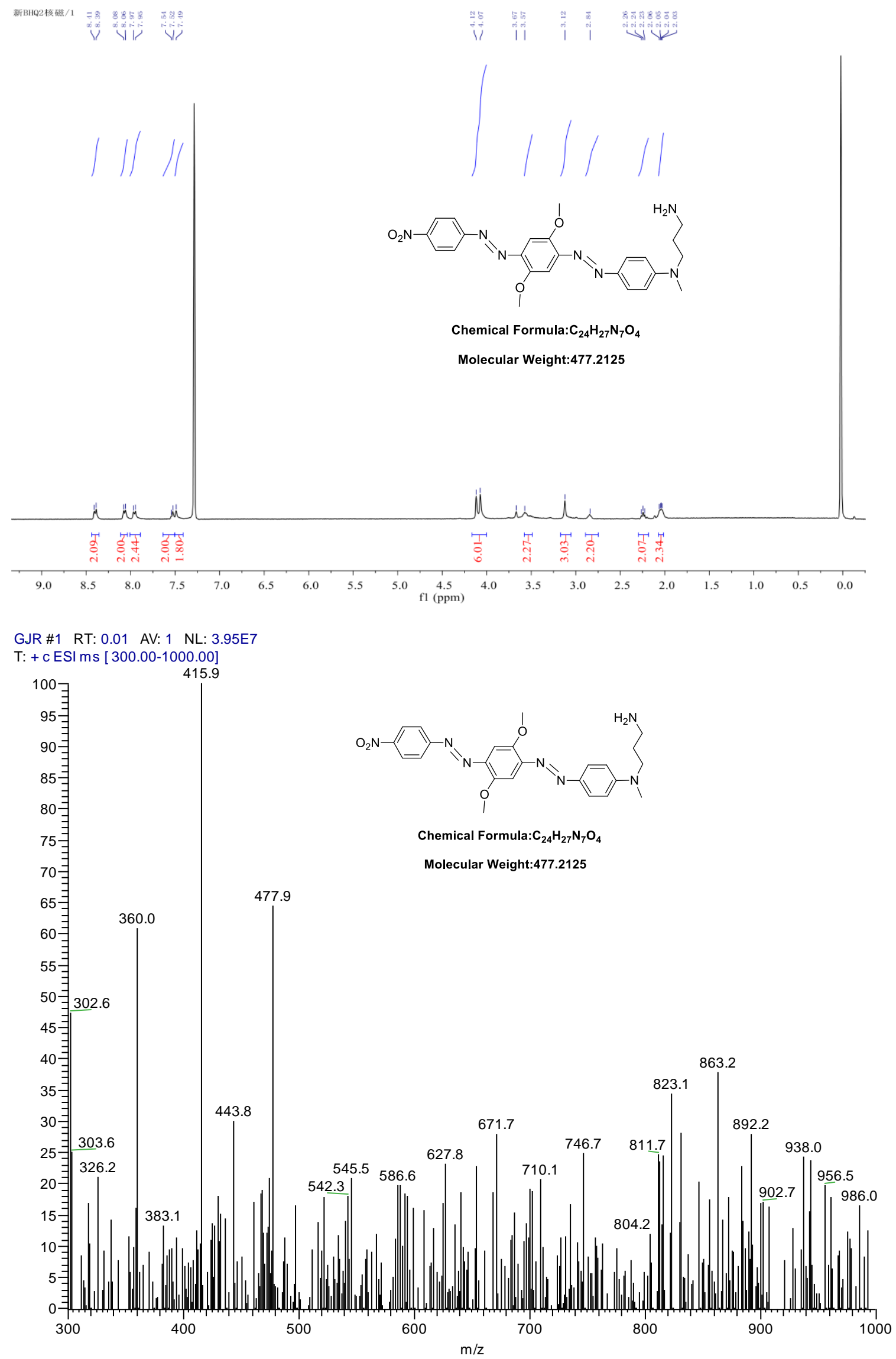




\section{References}

(1) Koopmans, C.; Ritter, H. Formation of Physical Hydrogels via Host-Guest Interactions of $\beta$-cyclodextrin Polymers and Copolymers Bearing Adamantyl Groups. Macromolecules 2008, 41, 7418-7422.

(2) Daihi, O.; Hirotatsu, K.; Yuki, T.; Toru, K.; Takuya, T.; Yoshinobu, T.; Tetsuo N. Near-Infrared Fluorescence Probes for Enzymes Based on Binding Affinity Modulation of Squarylium Dye Scaffold. Anal. Chem. 2012, 84, 4404-4410.

(3) Tang, J.; Kong, B.; Wu, H.; Xu, M.; Wang, Y.; Wang,Y.; Zhao, D.; Zheng, G.; Carbon Nanodots Featuring Efficient FRET for Real-Time Monitoring of Drug Delivery and Two-Photon Imaging. Adv. Mater. 2013, 25, 6569-6574. 